\title{
Representações do espaço em Fronteira, de Cornélio Penna
}

\author{
Representations of space in Fronteira, by Cornélio Penna \\ MAURA CAMARGO OLIVEIRA \\ Universidade Estadual de Mato Grosso do Sul - Campo Grande - Mato Grosso do Sul - Brasil \\ DANGlei De CAStro Pereira \\ Universidade de Brasília - Brasília - Brasil
}

\begin{abstract}
Resumo: O artigo aborda a caracterização do espaço no romance Fronteira, de Cornélio Penna como desdobramento de marcas de um processo criativo que aproveita elementos do gênero fantástico na ficção do autor. Investigaremos como a focalização narrativa conturbada contribui para a presença do caótico e do insólito, o que amplia a ambiguidade do romance em relação à caracterização das personagens centrais da narrativa. A proposta aborda a construção de uma narrativa ambígua perceptível na linguagem do romance, na focalização narrativa, na caracterização dos personagens e na representação mimética do espaço interiorano na primeira metade do século XX. Entendemos que o espaço inventivo e a ambiguidade do romance contribuem para a ambientação de Cornélio Penna ao contexto historiográfico modernista no Brasil.
\end{abstract}

Palavras-chave: Modernismo; Fantástico; Historiografia

\begin{abstract}
The article discusses the characterization of the space in the novel Fronteira, Cornélio Penna development of marks of a creative process that takes fantasy genre elements in fiction of Cornélio Penna. Investigate how the troubled narrative focus contributes to the presence of chaotic and unusual, which increases the ambiguity of the novel in relation to the characterization of the central characters in the narrative. The proposal addresses the construction of an ambiguous narrative noticeable in the romance language, the narrative focus in the characterization of the characters and mimetic representation of small-town space in the first half of the twentieth century. We understand that the inventive space and the romance ambiguity adds to the ambiance of Cornélio Penna to the modernist historiographical context in Brasil.
\end{abstract}

Keywords: Modernism; Fantastic; Historiography

\section{Introdução}

Cornélio Penna é um autor de difícil caracterização nos limites do Modernismo brasileiro, uma vez que sua obra transita entre o viés psicológico e o regionalismo ao aproveitar elementos do regionalismo de 1930 e traços do romance psicológico, o que indica uma confluência de tendências modernistas em sua narrativa, concordando com Bosi (1994).

Neste estudo, comentaremos a presença de aspectos do gênero fantástico na narrativa de Cornélio Penna, tendo como foco específico o romance Fronteira, o que entra em consonância com a ideia de hibridismo estético e temático na narrativa do autor. Nossa preocupação não é classificar Penna no âmbito específico do fantástico, antes comentar elementos do gênero em sua narrativa e, na medida do possível, discutir a ambiguidade do romance, tendo como pano de fundo uma ambiência insólita ligada ao espaço e a focalização narrativa no corpus.

Entendemos que as relações interpessoais entre Maria Santa e o narrador do romance são ambíguas, contribuindo, assim, para um espaço incerto de representação do real, no qual as descrições obscuras e duvidosas do espaço geram a hesitação entre o real e o sobrenatural, o que permeia a ambiência ao fantástico na narrativa via focalização caótica do espaço. Para nós o elemento insólito é aspecto importante na construção do romance e traço determinante na presença do fantástico no texto.

Antes de iniciarmos a discussão de nosso corpus apresentaremos, de forma sucinta, a obra do autor 
investigado com a preocupação de apresentar Cornélio Penna ao leitor deste estudo.

\section{Cornélio Penna: vida e obra ${ }^{1}$}

Nascido em Petrópolis/RJ Cornélio Penna é filho do médico Manuel Camilo de Oliveira Penna e D. Francisca de Paula Marcondes de Oliveira Penna. Cornélio Penna viveu parte de sua infância em Itabira/MG e Pindamonhangada/SP. Com o passar dos anos e, depois da morte do pai, fixa-se em Campinas/SP de onde sairia para o Rio de Janeiro em 1919. A partir desse ano, já bacharel em Direito, mora no Rio de Janeiro/RJ e trabalha como jornalista, começando a pintar e desenhar. Entre 1922 e 1930 abandona a pintura e se dedica à literatura.

Cornélio Penna foi funcionário público da Justiça e se casou com Maria Odília Queiroz Mattoso, com quem teve uma vida reclusa. Morreu em 1958 no Rio de Janeiro. Escreveu Fronteira (1935); Dois romances de Nico Horta (1939); Repouso (1949) e A menina morta (1954). Suas publicações compreendem cronologicamente as primeiras décadas do século XX e sugerem ligações com o romance psicológico no universo modernista. Segundo Bueno (2008), Cornélio Penna foi ligado ao movimento católico da época, formado pelos escritores Tristão de Ataíde, Lúcio Cardoso, Otávio de Faria, entre outros.

Para Bueno (2008),

Um dos hábitos conhecidos dessa crítica pioneira é assinalar a conversão de Cornélio Penna ao catolicismo, ocorrida em 1935, acrescentando-se que comungara no mosteiro de São Bento. Hoje esses dados, que nos soam estranhos, talvez funcionem como um índice para que se veja como funcionara a crítica ideológica, que teria marginalizado os romances do autor de 30. São ocorrências cujo registro, no entanto, se conserva, sendo curioso que a opção declarada do autor pelo catolicismo naquele ano seja sempre citada junto à data de publicação de Fronteira, tendo isso provavelmente corroborado para acentuar o viés religioso do romance, como um determinante direto em sua recepção crítica, e influindo, é claro, no julgamento dos que ainda viriam, vistos todos eles como romances católicos, pela chamada crítica de esquerda. (BUENO, 2008:16)

Na obra de Cornélio Penna a religiosidade é uma linha temática polêmica uma vez que a tensão religiosa encontra pontos de contato com a sensualidade e, por vezes, o erotismo. Bosi (1994) comenta que a narrativa do autor aproxima-se dos

\footnotetext{
1 Neste estudo, com relação às informações biográficas relativas a Cornélio Penna, tomamos por base a obra Um romance entre fronteiras: uma leitura do primeiro romance de Cornélio Penna de Terezinha Aparecida Perón Bueno.
}

[...] romances de tensão interiorizada. O herói não se dispões a enfrentar a antinomia eu/mundo pela ação: evade-se, subjetivando o conflito. Exemplos, os romances psicológicos em suas várias modalidades (memorialismo, intimismo, auto-análise...) de Otávio de Faria, Lúcio Cardoso, Cornélio Pena, Cyro dos Anjos, Lygia Fagundes Telles, Osman Lins... (BOSI, 1994:392)

Concordando, nesse momento, com os comentários de Bosi (1994) compreendemos que a subjetivação do herói nos romances psicológicos de Cornélio Penna ultrapassa questões puramente emocionais em direção a novos arranjos temáticos que problematizam o espaço social do qual emergem. Nas afirmações de Bosi (1994) Cornélio Penna é visto como sendo de um grupo de autores que faria parte de uma ambiência regionalista, mas que traz como especificidade o traço introspectivo.

Para Bosi (1994) o cenário literário entre 1930 a 1945 é ambientado em um conjunto eclético de tendências que se fundem como influência na literatura brasileira. Para o autor

Entre 1930 e 1945/50, grosso modo, o panorama literário apresentava, em primeiro plano, a ficção regionalista, o ensaísmo social e o aprofundamento da lírica moderna no seu ritmo oscilante entre o fechamento e a abertura do eu à sociedade e à natureza (Drummond, Murilo, Jorge de Lima, Vinícius, Schmidt, Henriqueta Lisboa, Cecília Meireles, Emílio Moura...). Afirmando-se lenta, mas seguramente, vinha o romance introspectivo, raro em nossas letras desde Machado e Raul Pompéia (Otávio de Faria, Lúcio Cardoso, Cornélio Pena, José Geraldo Vieira, Cyro dos Anjos...): todos, hoje, "clássicos" da literatura contemporânea, tanto é verdade que já conhecem discípulos e epígonos. E já estão situados quando não analisados até pela crítica universitária. A sua paisagem nos é familiar: o Nordeste decadente, as agruras das classes médias no começo da fase urbanizadora, os conflitos internos da burguesia entre provinciana e cosmopolita (fontes da prosa de ficção). Para a poesia, a fase 30/50 foi universalizante, metafísica, hermética, ecoando as principais vozes da "poesia pura" européia de entre-guerras: Lorca, Rilke, Valéry, Eliot, Ungaretti, Machado, Pessoa [...] (BOSI, 1994:386)

Entendemos que a obra de Cornélio Penna é tida como representação de um regionalismo que utiliza elementos psicológicos em um percurso narrativo introspectivo e subjetivo, o que aproximaria sua produção ao que Bosi (1994:386) denomina por "romance introspectivo".

Sua primeira obra, Fronteira, é publicada em 1935 e causou um estranhamento em grande parte da crítica, pois é uma narrativa em primeira pessoa que oscila entre as convenções do mundo religioso de Maria Santa e a representação emblemática e misteriosa das pequenas tensões urbanas do interior de Minas Gerais. 
A narrativa, por vezes, ultrapassa as adequações religiosas de traço católico em direção a uma tensão entre estes valores e o místico mesclados as tensões sociais da década de 1930. Para o Candido (1989)

Além do engajamento espiritual e social dos intelectuais católicos, houve na literatura algo mais difuso e insinuante: a busca de uma tonalidade espiritualista de tensão e mistério, que sugerisse, de um lado, o inefável, de outro, o fervor; e que aparece em autores tão diversos quanto Otávio de Faria, Lúcio Cardoso, Cornélio Pena, na ficção. (CANDIDO, 1989:188)

A partir das considerações de Candido (1989) e Bosi (1994) Cornélio Penna é considerado um autor que apresenta traços da linha católica espiritualista, mas focalizava tensões do "eu" envolto em um ambiente misterioso e ambíguo, no qual a temática religiosa é produto de tensões humanas dos protagonistas.

Nosso estudo pretende investigar aspectos do fantástico no romance Fronteira e, com isso, contribuir para a fortuna crítica do autor ao focalizar um aspecto temático ainda pouco explorado na obra de Penna.

\section{Entre a ficção e o fantástico: considerações preliminares}

As discussões sobre os limites da realidade empírica e os traços do sobrenatural na ficção tocam a abordagem de elementos que delimitam o sentido de natural e sobrenatural como espaço de construção do gênero fantástico, conforme Todorov (1993). Entendemos que na construção da ficção sempre é necessário um diálogo entre elementos do mundo real e suas projeções no âmbito ficcional. Sabemos, no entanto, recorrendo a Aristóteles (2001), que a ficção pode criar o seu próprio referente, seu mundo através dos seus elementos de construção. Em outros termos, espaço, tempo e as relações diegéticas que compõe o universo narrado estão intimamente relacionadas ao verossímil e a literariedade de dado texto.

Silva (2013) comenta que a arte literária cria seu próprio referente através do mundo ficcional. O fantástico, assim como a ficção tradicional, opera um deslocamento consciente da representação objetiva da realidade nos limites da ficção e, nesse caso,

o mundo da ficção, portanto, é um ato de criação que pode ou não estar fiado no real, que segue seu próprio fluxo, muitas vezes com personagens e situações (um quarto na ficção realista, por exemplo, será sempre um quarto) roubadas diretamente do mundo, como diria Julio Cortázar, mas pode que acompanhar um fluxo interno sui generis, como demonstrado pela revitalização da mímesis operada por Costa Lima. (SILVA, 2013:42)
A realidade empírica de caráter mais objetivo e palpável encontra no fantástico um espaço de fragilidade; pois, no fantástico, a realidade é uma ficção que, muitas vezes, ultrapassa o paralelo empírico de forma direta e cada personagem possui uma representação imaginária daquilo que "vê" ou percebe como natural.

Para Cortázar (2006) no fantástico a representação empírica encontra um espaço polêmico e, nesse caso, os limites fixos entre natural e sobrenatural são flexibilizados, pois, para o autor,

[...] no meu caso, a suspeita de outra ordem mais secreta e menos comunicável, e a fecunda descoberta de Alfred Jarry, para quem o verdadeiro estudo da realidade não residia nas leis, mas nas exceções a essas leis, foram alguns dos princípios orientadores da minha busca pessoal de uma literatura à margem de todo realismo demasiado ingênuo. (CORTÁZAR, 2006:148)

Essas exceções às leis empíricas estão no que Cortázar denomina por reorganização do "realismo demasiado ingênuo". Conforme Cortázar (2006) tudo é ficção, pois fazemos uma representação do mundo que nos rodeia ao manipularmos a linguagem e isso, segundo o autor, não é diferente na ficção tradicional. Concordando com o autor, entendemos que a relação entre natural e sobrenatural é estreita no fantástico, uma vez que a ficção é a arte da "representação representada", podendo ou não estar relacionada ao "real" empírico.

Novamente recorrendo a Todorov (1993:31) “o fantástico ocorre nesta incerteza; ao escolher uma ou outra resposta, deixa-se o fantástico para se entrar num gênero vizinho, o estranho ou o maravilhoso". É na incerteza, na hesitação de uma resposta pontual entre natural e sobrenatural que o fantástico se configura. Sendo assim, o fantástico se apresentará na incerteza, na hesitação do personagem e, também, do leitor diante do fato descrito como real.

Breve coda sobre os contos fantásticos. Primeira observação: o fantástico como nostalgia. Toda suspension of disbelief [suspensão da incredulidade] atua como uma trégua no seco, implacável assédio que o determinismo faz ao homem. Nessa trégua, a nostalgia introduz uma variante na afirmação de Ortega: há homens que em algum momento cessam de ser eles e sua circunstância, há uma hora em que desejamos ser nós mesmos e o inesperado, nós mesmos e o momento em que a porta que antes e depois dá para o saguão se abre lentamente para nos deixar ver o prado onde relincha o unicórnio.Segunda observação: o fantástico exige um desenvolvimento temporal ordinário. Sua irrupção altera instantaneamente o presente, mas a porta que dá para o saguão foi e será a mesma no passado e no futuro. Só a alteração momentânea dentro 
da regularidade delata o fantástico, mas é necessário que o excepcional passe a ser também a regra semdeslocar as estruturas ordinárias entre as quais se inseriu. (CORTÁZAR, 2006:235)

O fantástico deverá se apresentar de forma sutil, pois deve "deslocar as estruturas ordinárias" em relação ao não natural. Por conta deste procedimento, deslocamento sutil do real natural em direção ao sobrenatural, o fantástico refletirá elementos da normalidade em padrões específicos de organização da linguagem, por vezes, caóticos e insólitos face ao que se convenciona entender como normal ou real empírico. Neste percurso, realidade e ficção flertam em direção ao sobrenatural e, por vezes, flutuam entre o previsível e a surpresa, o que será uma "regra" da narrativa fantástica sem alterar sua estrutura aparentemente real e objetiva, retomando as considerações de Cortázar (2006).

Feitas estas considerações, mesmo que sucintas, sobre o fantástico partiremos para a discussão do romance Fronteira e investigaremos traços do fantástico no romance em discussão.

\section{Uma leitura de Fronteira de Cornélio Penna}

Fronteira, publicado em 1935, é a primeira obra literária de Cornélio Penna. Cronologicamente é um romance modernista da geração de 1930 e corresponde às tendências da época sendo compreendido, muitas vezes, como romance introspectivo. Para Ávila

trata-se do espaço do subsolo, grosseiramente correspondente ao que tem sido chamado romance psicológico e / ou da angústia religiosa... Por espaço do subsolo entendemos o que comporta, em relação não exaustiva, Cornélio Pena, Guimarães Rosa, Monteiro Lobato, Ciro dos Anjos, Lúcio Cardoso e que, atualmente, se prolonga em certo Autran Dourado. (ÁVILA, 2002:71)

O texto narra uma história recheada de mistério e dúvidas. $\mathrm{O}$ narrador autodiegético chega a uma cidade e se instala na casa de Maria Santa, personagem mística em uma comunidade interiorana de Minas Gerais. O percurso diegético acompanha a trajetória de Maria Santa, personagem central do romance, durante a Semana Santa até sua morte. Maria Santa é figura central no enredo, mas o narrador se estabelece de forma ambígua em torno da personagem e de sua trajetória enquanto "santa". A focalização oscila entre a descrição da vida de Maria Santa e a forma caótica com que o narrador lida com estas informações ao longo do enredo.

$\mathrm{O}$ narrador tem incertezas sobre o estado civil de Maria e, assim, inferimos certo interesse pessoal pela personagem: “(...) levei muito tempo sem saber se ela [Maria Santa] era agora viúva, solteira ou mesmo casada." (PENNA, 197?:14). Ao utilizar o termo "agora" vislumbra-se a possibilidade de um contato anterior entre Maria Santa e o narrador que, no presente, comentaria suas impressões em relação ao passado. Esta impressão de intimidade acompanha o foco narrativo ao longo do romance, ampliando um tom ambíguo entre os personagens. As lembranças dos personagens, narrador e Maria Santas, são contraditórias e envoltas em certa nebulosidade como, por exemplo, o fato de Maria Santa não saber se é ou não casada: "já faz tanto tempo que as [par de alianças] tenho que não me lembro se são minhas ou eram de minha mãe." (PENNA, 197?:14).

Essas informações contraditórias são ampliadas por um possível parentesco entre os personagens que coabitam a casa e leva a inferência de um possível retorno do narrador ao lar depois de um momento de distanciamento, o que indica um dos aspectos da ambiguidade do romance. O narrador parece conhecer o espaço da "casa" e seus habitantes, mas não os compreende ou se identifica com eles. É a partir da construção deste narrador identificado ao espaço da narrativa e que demonstra dificuldades em conviver com os moradores da casa, que se percebe a tensão entre o personagem e as cenas que descreve.

O caráter obscuro e indeterminado do espaço parece contribuir para a fragilidade psicológica dos personagens do romance como pode ser visto na descrição da chegada do narrador à casa: "chegamos - afirma quem me acompanha, ao ver-me imóvel, sem coragem para descer, sem ânimo de perguntar o que quer que seja. (e amparame nos braços enquanto murmuro para mim, baixinho: "é minha casa...")." (PENNA, 197?:12). Verificamos que o narrador possui uma relação de pertencimento ao espaço da casa. A afirmação de que "é minha casa" confirma tal pertencimento, mas o desanimo diante do espaço parece indicar um traço negativo "sem coragem para descer".

É como se o narrador identificasse o pertencimento, mas não fosse de sua vontade adentrar no espaço, uma vez que demonstra uma contrariedade e um desanimo diante do retorno. A oscilação de se reconhecer como pertencente ao espaço indica uma fragilidade psicológica que o acompanhará ao longo da narrativa e fará com que as descrições do espaço sejam sempre ambíguas aos olhos de um narrador reticente e receoso por encontrar e enfrentar elementos do passado.

A tensão entre pertencer e não pertencer ao espaço marca uma homologia entre a trajetória do narrador e a relação ambígua que constrói com este espaço e, posteriormente, com Maria Santa. A narrativa parece conduzir a uma fragmentação do narrador que vive na ambiguidade do espaço e na relação complexa com os demais personagens, sobretudo, Maria Santa e Tia 
Emiliana. Esta tensão levará a um processo complexo de reconhecimento de sua identidade, vista de forma fragmentada pela relação com o espaço da casa e da cidade provinciana focalizada em Fronteira.

Entendemos que a ambiguidade face ao espaço contamina a relação entre o narrador e a personagem Maria Santa em um ar de inquietação e perturbação que beira a inferência amorosa e a presença de uma crise psicológica.

Outro dia nossos olhos se encontraram, quando nos achávamos em uma das salas internas. E sentimos que eles nos denunciavam, simultaneamente.

- Mas aqui nada se passa! - exclamou Maria Santa, com febril impaciência - e eu não quero saber das mentiras que me cercam, ou quem quer que seja venha me contar.

Era estranha a crescente perturbação que se fazia sentir sua voz e nos seus olhos, que se desviavam medrosamente dos meus, enquanto eu a seguia, acompanhando o ritmo maquinal de seus passos muito largos, um pouco arrastados, pois estava abstraída do que a cercava, e tirava de seus lugares a manga de vidro, os castiçais e as flores de madrepérola, que nunca saíam de sobre os aparadores. (PENNA, 197?:32)

Os olhos que se encontram e "se denunciam" no isolamento de um aposento íntimo - sala interna revela a perturbação dos personagens. As "mentiras do passado" e a oscilação entre uma afetação emotiva contamina os personagens e expõe o estado de agonia e agitação de olhos que fogem "medrosamente" a cada encontro entre o narrador e Maria Santa. Esta "estranha e crescente perturbação" é marcada por uma mudança efêmera no espaço como prolongamento da tensão dos personagens, sobretudo, Maria Santa, que nervosamente retira os objetos "a manga de vidro, os castiçais e as flores de madrepérola”, revelando certa agitação íntima da personagem; sentida pela mudança de comportamento e pelos olhos medrosos que se encontram e revelam a presença de um passado comum.

O passado comum gera uma tensão relacionada aos sentimentos entre os personagens e tem como índice o ambiente da casa e a ambiguidade narrativa. $\mathrm{O}$ espaço representado no romance, por vezes, adquire uma representação alienante, pois o narrador estabelece uma visão conturbada face às cenas que descreve.

Poderia jurar que um besouro voava pela sala, tentando fugir, porque seu zumbido monótono reboava em minha cabeça $[. .$.$] mas, de repente o ruído crescia,$ tornava-se muito alto, ameaçador, espantoso, e eu tinha a sensação, súbita, de uma queda brusca, e despertava em sobressalto, com o silêncio que se fazia na sala, por um segundo (PENNA, 197?:20)
O excerto começa por questionar o espaço ao focalizar o voo do "besouro". Este voo, no entanto, cria a ambiguidade na medida em que a observação do espaço vai adquirindo traços psicológicos, pois a focalização condiciona um processo introspectivo a partir da referência ao "reboo" do besouro na sala. A interferência do silêncio leva a uma espécie de transe do narrador que vê o "reboo" do besouro projetado em sua cabeça, "reboava em minha cabeça". Na sequência da cena, o ruído do besouro provoca o deslocamento espacial do narrador em direção a uma atitude pessoal e íntima, quase onírica, pois ele parece flutuar no espaço "eu tinha a sensação, súbita, de uma queda brusca e despertava em sobressalto, com o silêncio que se fazia na sala, por um segundo." (PENNA, 197?:20).

Observamos que o espaço estabelece um elo entre o narrador e as lembranças do passado por meio da polêmica aproximação as lembranças e a Maria Santa. Muitas vezes, o foco narrativo oscila entre a descrição objetiva da casa e o "sonho". A realidade é introjetada de forma a representar a oscilação psicológica do narrador e, com isso, projeta uma possibilidade onírica para a compreensão da cena que descreve "despertava em sobressalto".

A oscilação entre a realidade e onírico é uma das marcas do fantástico no romance e cria o efeito introspectivo diante do espaço; gerando a agonia do narrador como, por exemplo, a sensação de abismo que a descrição do voo do besouro provoca. O narrador compreende as tensões envolvidas nas relações pessoais na casa que, por isso, permeiam o espaço e o tempo da narrativa, criando uma nevoa que turba as sensações e convicções do narrador. Esta oscilação entre o real e o onírico é percebida na apresentação da fala do juiz que "[..] prosseguia falando sempre, e o rumor de sua voz, prolongando o zonzonar que me enchia os ouvidos, davame, logo depois, uma impressão de irreal, de fantástico" (PENNA, 197?:20).

O caos sonoro da cena descrita no excerto citado é produzido pela sobreposição do som do voo do besouro e da fala do juiz, o que cria uma sinestesia inusitada que projeta a apresentação do espaço amalgamada ao som do besouro, provocando o deslocamento do personagem do fluxo objetivo em direção ao que ele compreende como “impressão de irreal, de fantástico". Esta transposição é ampliada pela representação que o narrador faz das suas percepções sonoras e visuais ao longo do romance. Muitas vezes a transição entre real e sobrenatural é materializada no progressivo distanciamento de Maria Santa face à realidade e a dificuldade do narrador compreender sua trajetória individual e, por consequência, a de Maria Santa no espaço nebuloso do romance.

Um exemplo do que foi dito é a reação de Maria Santa na conversa entre ela, o narrador e o juiz. O 
diálogo é permeado por uma tensão: “[...] o rosto e os olhos de Maria Santa, perdiam, como os de um gato em repouso, pouco a pouco, o seu brilho, e completavam a esquisita sensação que sentia." (PENNA,197?:20). A "esquisita sensação que sentia" é direcionada a trajetória do narrador enquanto personagem e não a Maria Santa. A sensação de abandono, alienação ou angústia transita entre Maria Santa e as sensações do narrador ao observar a personagem em sua aparente letargia de doente.

Reforçando o caráter ambíguo da obra, o narrador apresenta o espaço de forma incerta e, por vezes, duvida das impressões que consegue captar diante do real. Esta confusão na descrição é ampliada pela visão altamente subjetiva do narrador que transita de forma direta das sensações íntimas que vivencia para uma tentativa de compreensão racional do espaço que o cerca. Ao focalizar perifericamente os acontecimentos na casa de Maria Santa, a caracterização de um narrador homodiegético é ampliada pela forma individual com que desloca o olhar em direção a suas impressões pessoais sobre o universo narrado, possibilitando uma ambiguidade narrativa e, por vezes, apresentado uma visão autodiegética das cenas que descreve.

Entendemos, então, que na medida em que o narrador desloca o olhar em direção a sua trajetória individual; deixa em segundo plano a trajetória de Maria Santa, possível protagonista da narrativa, revelando uma forma ambígua de focalização no romance. Este jogo de narradores - transposição de homodiegético para autodiegético - contribui para a ambiguidade do romance e imprime o olhar individual diante do cenário que é apresentado ao leitor.

É na forma de narrar que reconhecemos o caos que a descrição do espaço assume em Fronteira; outro aspecto fantástico identificado no romance. Nesse caso, a casa de Maria Santa assume importância estrutural na obra, pois indica a presença do passado e a dificuldade de mudanças; elemento que amplia a angustia dos personagens:

E foi então que quis fugir, afastar de mim aquele ambiente que me pesava, sufocante, como um grande véu. Quis saltar por sobre o círculo mágico que me cingia, cada vez mais apertado; quis ver lá gora o mundo quotidiano, os dias que passam sem análise, rosto e olhos sem segundos planos, que choram e olham muito iguais, com a mesma luz e as mesmas lágrimas de sempre... (PENNA, 197?:47-48)

Compreendemos a partir do trecho acima, que o espaço da casa é um espaço que sufoca e pesa sobre o narrador. Os segredos e a complexa relação entre os personagens indicam uma "fratura" entre o real e o sobrenatural. Reconhecemos que a construção do espaço contribui para a presença de marcas do fantástico em
Fronteira. Porém é nas incertezas (no não dito) de um narrador autodiegético oscilando para uma abordagem homodiegética que as impressões do personagem periférico, visitante em casa de Maria Santa, gravitam ambiguamente em torno da trajetória de Maria Santa a projetar nela, Maria Santa, suas incertezas e fragilidades.

As marcas do fantástico no romance são perceptíveis na oscilação entre o plano objetivo ao focalizar Maria Santa e sua história e, o insólito, das sensações evocadas pela figura ambígua de Maria Santa na trajetória do narrador que, por isso, nesse plano narrativo, assume uma conotação importante da construção do olhar sobre o espaço no romance. A presença do sobrenatural e, por vezes, do insólito ganham força na organização diegética, na medida em que o real oscila para imagens sobrenaturais; outro traço fantástico no romance.

Vejamos este aspecto no excerto que segue:

Senti-me bem. Um bem-estar repentino e absoluto, que me fez conter a respiração, apesar das lufadas de ar puro, que vinham das entradas do vale, e chegavam intatas até aquele alto.

Mas, uma suspeita, leve a princípio, depois inquieta, e progressivamente angustiosa, fez com que eu me agarrasse ao varão de ferro da janela sem portadas, e pareceu-me que flutuava hesitante, entre o céu e a terra, naquela luz azul, depois ultramar, finalmente púrpura, e, por muito tempo, muito tempo, esqueci-me de mim.

- Quem está ai?

E a voz do homem subiu pela caixa da escada, como se viesse em minha procura, e me envolvesse em suas ondas invisíveis. Um terror pânico imenso agitou-me os nervos todos, e desci os degraus oscilantes, atravessei a nave agora em trevas, e fugi, sem me lembrar que corria justamente para o coração da cidade, para junto dos próprios remorsos que me perseguiam, e dos seus vestígios...(PENNA, 197?:51)

No excerto, observamos que a incerteza se instala no narrador através da sobreposição do real ao sobrenatural (aquilo que foge a regra do real na narrativa). O narrador em visita a uma igreja vazia não sabe se os sons que ouve são reais ou ilusão "Quem esta aí?". É em um momento de suspensão, "esqueci-me de mim", que surge a voz que "persegue" o narrador e indica "ondas invisíveis de terror". A presença do sobrenatural ao revelar elementos que sugerem o demoníaco indica a existência de "fantasmas do passado" que assolam a memória do narrador e o projetam para os "vestígios" do passado que assombram o narrador.

É através de um narrar nebuloso que, por vezes, não consegue compreender o espaço que observa que a narrativa se constrói. Esta oscilação - real e sobrenatural - será uma "regra" da narrativa ficcional, mas para 
Cortázar (2006) é a essência do fantástico. É por meio do ato de narrar e na construção do espaço na relação com os personagens que identificamos mais uma marca do fantástico no romance.

Entendemos, no entanto, que a oscilação real e sobrenatural indica a base para a construção das relações ambíguas entre as personagens do romance vistas, muitas vezes, de forma insólita:

Diante do corpo sem consciência de Maria Santa, fiquei imóvel durante minutos eternos, antes de estender as mãos, e tocar com elas a prova real do que se passava em mim, e pude, afinal percorrer, agora já sem medo, os seus seios fortes, extraordinariamente fortes na linha alongada do perfil do seu corpo estendido, todo iluminado por uma luz unida, mágica e mole, que fazia transparecer, como um trabalho de marfim antigo, a caveira mal oculta pela carne lívida e translúcida.

As imagens de Tia Emiliana, envoltas em seus mantos suntuosos de veludo, fitavam-me com seus olhos exageradamente patéticos, de onde pendiam grossas lágrimas de parafina, que escorriam sobre as faces de cor cadavérica, apesar das manchas de vermelhão, e os pesados ramalhetes de flores de metal, como mitras de bispos de pesadelo, as velas de cera, muito altas e hirtas, as rendas e franjas douradas e prateadas, em profusão, tornavam tudo que me cercava irreal, estranho, sustentando com seu ingênuo e esquisito artifício a minha pobre tentativa de vida e de humanização.

Não me parecia cometer um crime moral, ao desvendar vagarosamente, um a um, os melancólicos segredos daquele corpo que todo se me oferecia e se recusava, ao mesmo tempo, em sua longínqua imobilidade. (PENNA, 197?:86)

Neste trecho temos a descrição de um momento entre o narrador e Maria Santa que está inconsciente sob o olhar de Tia Emiliana. A percepção dos "seios" no olhar que o narrador desfere ao corpo imóvel de Maria Santa é marcado por um possível desejo carnal. A ambiguidade é ampliada pela descrição do espaço onde se estabelece o contato, pois o quarto de Maria Santa, adornado por imagens de santos, é assombrado pelo tom mortuário e sombrio que antecede a morte da personagem.

O narrador apresenta, então, uma relação passional com Maria Santa, mas associa esta relação ao pecado como a um ato de profanação:

Intensa e irresistível vergonha subiu-me ao rosto, e, quando Maria Santa se destacou do fundo negro do recanto onde se refugiara, em cujas sombras o seu corpo se confundia, e avançou para mim, como a figura de um quadro negro antigo, que abandonasse o seu fundo de betume, eu estendi as mãos, como para fazêla parar, como se pedisse que me poupasse. $[\ldots]$

Deixei-me cair de joelhos, tremendo, e disse com voz sufocada:

- Talvez esse sacrifício que faz seja para me salvar, Maria Santa, e eu a bendigo por essa intenção de misericórdia...

Ela afastou-se vivamente, como a um contato escaldante, e, tornando-se ainda mais pálida, murmurou, entre dentes:

- Talvez?... talvez... talvez eu queria salvar-me!

E parou alguns instantes, refletindo, como se procurasse, dolorosamente, no fundo de si mesma, alguma coisa para dizer-me, e que me ocultasse definitivamente o seu pensamento, ou o esclarecesse de forma total.

Depois , num sopro:

- Ou talvez... queira perder-me... (PENNA, 197?:60-61)

A ambiguidade passional percorre o romance. Maria Santa parece desejar o narrador e se insinuar para ele "avançou para mim", porém o narrador a afasta e, em seguida, assume um tom de santidade e purgação "talvez eu queria salvar-me". Esse ato de repelir também marca a ambiguidade da relação entre Maria Santa e o narrador, pois, nesse trecho, o narrador nega a posse física; porém, em outros trechos, fica inferido que o desejo carnal é de fato algo real e o desejo contido amplia o desespero dos personagens.

Como a história é contada em primeira pessoa temos o ponto de vista de uma personagem sobre os fatos ocorridos e esse ponto de vista é também notado pelas suas percepções de espaço e pela representação das outras personagens na diegese. Outra questão importante para o romance é a insinuação de uma cadeia de relacionamentos anteriores, repletas de incertezas e ódio.

São homens e mulheres: são criaturas humanas que nunca vi e que nunca me viram; amanhã serão meus amigos e meus inimigos, e formarão em torno de mim uma cadeia cerrada de ideias e de ódios que ainda me não pertencem. (PENNA, 197?:13)

O espaço da casa de Maria Santa é visto como prolongamento desta cadeia de sentimentos não revelados, mas, sobretudo, "não consumados". O aprisionamento ao passado indica que as relações humanas em Fronteira são construídas por reminiscências, indicando a ambiguidade dos diálogos, quase sempre, vazios de significado e que encontram na impossibilidade de compreensão do narrador um traço insólito como única possibilidade de convivência entre os personagens do romance descritos, ironicamente, como "criaturas humanas que nunca vi".

O narrador identifica nas relações humanas, convivência no passado, uma luta de forças no interior da narrativa. Há nuances entre a sanidade e a loucura do 
narrador e Maria Santa, materializadas entre a santidade e o demoníaco que cerca a convivência entre os personagens na casa.

Foi por isso que Tia Emiliana me recebeu como se fosse a própria Providência Divina que surgisse, com suas luzes, naquela sala escura e sinistra, com seu misterioso alçapão de pesadas argolas de ferro, muito empoeiradas e enferrujadas, a demonstrar os anos que lavavam imóveis, intatas, e mal tapavam o riacho murmurante que passava por debaixo das arcadas da velha casa, e cujas águas, com seu murmúrio incessante, me enervavam e irritavam. Uma escada erguia-se abruptamente, e penetrava de modo brutal na muralha muito larga, subindo para o sótão, tendo um grande Arcanjo São Miguel, grosseiramente esculpido e pintado, que servia de suporte ao teto, e de pilastra para o áspero corrimão. (PENNA, 197?:45)

Esse tipo de descrição demonstra que é o espaço que fornece a ligação entre as personagens e as relações com o passado, pois a "velha casa" é o elemento conhecido; comum a todos e que unifica as trajetórias de cada personagem como prolongamento de uma convivência anterior. É pela casa velha, cheia de santos e demônios que penetramos no interior das personagens e, na sequência, ao clima misterioso, sinistro e sobrenatural que percorre as relações humanas no romance. Entendemos que Maria Santa ocupa um papel de destaque na narrativa e oscila entre o humano e a santidade, mas o espaço da casa é fator importante na construção da ambiguidade narrativa e, por isso, o espaço da casa é importante na caracterização de elementos do fantástico no romance.

No fragmento abaixo observamos a oscilação do natural em direção ao sobrenatural permeado pelo espaço da casa, pois no quarto fechado os móveis velhos e empoeirados começam a se mover sem explicação prévia.

Mas alguma coisa a chamou a si, porque logo se acalmou, e apontou para a porta de um quarto que dava para a sala interna onde estávamos, e disse com seca ironia:

- Está me observando? Quer saber tudo? Quer ver verdade? Ali, atrás daquela porta, naquele quarto, está a verdade.

A principio nada vi. Era o mesmo quarto de sempre com sua cama muito larga e pesada, de cabiúna, uma cômoda baixa, vazia, e duas mesas - de - cabeceira.

Que segredo guardariam aqueles móveis velhos e cansados?

Aproximei-me do leito, e contemplei-o com o olhar suspeitoso.

Colchões e travesseiros, enormes, levemente cobertos de poeira, estavam em ordem, com o pano desbotado pelo tempo. Mas pouco a pouco, diante de meus olhos dilatados pela atenção, as suas flores, de um vermelho longínquo, começaram a se mover, aumentaram e espraiaram-se, ora juntando-se em desenhos esquisitos, ora separando-se, em fuga rápida, e se escondiam nos grandes rebordos do espaldar.

Pareciam de sangue seco, restos de crime..

Pareciam de sangue cansado, débil, esbranquiçado...

Pareciam de sangue espumoso, lembrança de ignóbeis volúpias...

Pareciam de sangue.

Recuei com repugnância, e senti, como se tivesse pousado sobre o colchão as minhas mãos, o cavado dos corpos em suor, agitados por inomináveis estremecimentos. Que gemidos alucinantes teriam batido de encontro àquelas almofadas de madeira, com grandes veios escuros, como o dorso da mão do diabo, de envolta com odores mornos de gozo e brutalidade.

Todo o quarto parecia agora viver intensamente, e sentia em meus ouvidos um clamor de vida pecaminosa, trêmula, indecente, do crime humano da reprodução, e o seu ambiente poderoso, entontecedor de crueza e nudez, envolveu-me em sua onda amarga.

Recuei mais ainda, e, sentindo atrás de mim as folhas da porta, abria-a, e fugi sem destino certo... (PENNA, 197?:36-37)

Conforme podemos perceber neste fragmento, o insólito ocorre em uma justaposição à normalidade da narrativa, sutilmente engendra ao plano objetivo da descrição da casa e dos personagens. O estranho e o inexplicável do ponto de vista da narrativa natural "era o mesmo quarto" assumem tons insólitos na indicação de um passado não revelado ao leitor. Em outros termos, o sobrenatural parece conviver na descrição ambígua dos fatos diegéticos que se apresentam ao leitor pela objetividade da casa, mas que são mesclados ao tom subjetivo que o narrador imprime ao espaço. No excerto, é como se o quarto e seus objetos fossem "pessoas" que ali viviam e começaram a contar suas histórias; das quais o narrador sempre foge.

É a oscilação entre o real e o sobrenatural que impele o narrador à fuga no excerto citado. Teríamos, então, uma fronteira entre o natural e a ambiguidade das cenas narradas no romance, o que levaria a presença do sobrenatural em um espaço de convivência com o natural. Sendo assim podemos compreender que no romance Fronteira as marcas do fantástico se apresentam de forma a manter o equilíbrio da narrativa, sem alterar sua estrutura.

Existe uma flutuação entre o real e o sobrenatural, organizando o encadeamento narrativo. É como se o espaço físico da casa assumisse uma função lacunar na narrativa e, por isso, funciona como mecanismo para a ampliação de intrigas e lembranças ambíguas ligadas ao passado da família visto pelos olhos conturbados de um narrador em crise que não consegue identificar o que é real e insólito em sua polêmica focalização. 
Suas salas gigantescas e toscamente construídas eram mobiliadas com raros móveis muito grandes, de pau-santo, rígidos e ásperos, e davam a impressão de que os avós de Maria, seus antigos possuidores, levavam uma vida de fantasmas, em pé diante da vida, só se sentando ou recostando, quando doentes, para morrer.

Era uma casa feita de acordo com o cenário de montanhas que a cercavam de todos os lados, e não feita pra servir de quadro e abrigo para os homens que a tinham construídos com suas próprias mãos. (PENNA, 197?:15)

Observamos que a casa é descrita de forma a remeter ao insólito, pois é mobiliada de móveis raros e muito grandes e o vazio entre estes móveis abrigaria "fantasmas" do passado que parecem preencher estes espaços vazios. O contraste entre a construção secular e a presença do passado é apresentado de forma rígida e áspera no romance como a reforçar caráter duro e obscuro das pessoas que convivem e conviveram neste ambiente; esperando, todos, como "doentes, para morrer".

Entendemos que a ambiguidade parece ser o ponto de ligação entre os personagens e o espaço no romance e, por isso, oferece suporte para a presença do insólito e das marcas do fantástico que procuramos evidenciar ao longo da discussão do romance.

\section{Considerações finais}

Conforme a nossa proposta de investigação, discutimos a presença de tensões entre o real e o fantástico na ficção de Cornélio Penna, mais especificamente, no romance Fronteira. Desta ambiguidade, compreendemos que a focalização ambígua do narrador e as descrições dos personagens em um espaço nebuloso contribuem para o surgimento de marcas do fantástico no romance.

É a partir da ambiguidade do narrador que desenvolvemos nossa reflexão, pois, para nós, é através de um narrador que focaliza de forma incerta aquilo que está a sua volta que as marcas do fantástico são perceptíveis no romance. Pensamos, ainda, que com a leitura do romance Fronteira contribuímos para a discussão da obra de Cornélio Penna e, com isso, demonstramos a preocupação em valorizar traços constitutivos de sua narrativa e favorecer a constante revisão da historiografia literária brasileira.

Fica evidente, porém, que não tencionamos classificar Cornélio Penna como um autor fantástico; antes indicar que este é caminho que contribui para a compreensão de sua fortuna crítica, muitas vezes, pouco conhecida do grande público.

\section{Referências}

ABDALA JUNIOR, Benjamin; CAMPEDELLI, Samira Youssef. Tempos da literatura brasileira. São Paulo: Ática, 1997.

ARISTÓTELES. Arte poética. Disponível em: <http://www. dominiopublico.gov.br/pesquisa/DetalheObraForm.do?select action=\&co_obra=2235>. Acesso em: 21 jul. 2014.

ÁVILA, Affonso. $O$ modernismo. São Paulo: Perspectiva, 2002.

BOSI, Alfredo. História concisa da literatura brasileira. São Paulo: Cultrix, 1994.

BRITO. Mário da Silva. História do modernismo brasileiro: antecedentes da Semana de Arte Moderna. Rio de Janeiro: Civilização Brasileira, 1997.

BUENO, Teresinha Aparecida Peron. Um romance entre fronteiras: uma leitura do primeiro romance de Cornélio Penna. Dissertação (Mestrado em Letras) - Faculdade de Filosofia, Letras e Ciências Humanas do Departamento de Teoria Literária e Literatura Comparada, Universidade de São Paulo, São Paulo, 2008 .

CANDIDO, Antonio. A educação pela noite \& outros ensaios. São Paulo: Ática, 1989.

CORTÁZAR, Julio. Valise de cronópio. São Paulo: Perspectiva, 2006.

CHKLOVSKI, V. A arte como procedimento. Disponível em: $<$ http://pt.scribd.com/doc/27946060/CHKLOVSKI-V-A-artecomo-procedimento-In-Teoria-da-Literatura-FormalistasRussos>. Acesso em: 22 jul. 2014.

DIMAS, Antônio. Espaço e romance. São Paulo: Ática, 1987.

HELENA, Lúcia. Modernismo brasileiro e vanguarda. São Paulo: Ática, 1996.

PENNA, Cornélio. Fronteira. Rio de Janeiro: Ediouro, [197?].

SILVA, Frederico José Machado. Sobre o mundo da ficção: fronteiras, definições e inconsistências. In: FARIAS, Sônia Ramalho de; PEREIRA, Kleyton Ricardo Wanderley. Mímesis e ficção. Recife: Pipa Comunicação, 2013. p.15-43.

TODOROV, Tzvetan. Introdução à literatura fantástica. São Paulo: perspectiva, 1993.
Recebido: 06 de abril de 2015 Aprovado: 18 de maio de 2015 Contatos: danglei@terra.com.br mauracamargo@hotmail.com 